\title{
Changes in Soil Enzymatic Activity Caused by Hydric Stress
}

\author{
Karolina Furtak $^{1 *}$, Anna Gałązka ${ }^{1}$, Jacek Niedźwiecki² \\ ${ }^{1}$ Department of Agricultural Microbiology, Institute of Soil Science and Plant Cultivation, \\ State Research Institute, Puławy, Poland \\ ${ }^{2}$ Department of Soil Science Erosion and Land Protection, Institute of Soil Science and Plant Cultivation, \\ State Research Institute, Puławy, Poland
}

Received: 17 June 2019

Accepted: 8 October 2019

\begin{abstract}
The increase in flooding in Europe is linked to the presence of excessive moisture in many areas. Enzymes are a sensitive parameter of soil environment, therefore we have made an attempt to assess the impact of simulated flood conditions on their activity. We determined the activity of dehydrogenases and acid and alkaline phosphatase after 7 and 14 days of flooding the three Fluvisols with river water in controlled conditions. The obtained results indicate a significant influence of soil moisture on enzymatic activity and soil $\mathrm{pH}$, which indicates that the soil environment is changing as a result of flooding.
\end{abstract}

Keywords: consequences of flooding, dehydrogenases activity, phosphatases activity, soil moisture, water stress

\section{Introduction}

Natural changes in soil moisture associated with the cyclical nature of seasons directly affect microbial metabolism. However, long-term water retention in areas where it does not occur naturally affects the biological activity of soils. The availability of molecular oxygen in the soil affects many processes: the oxidation and reduction of minerals, the development of appropriate microbial groups and their enzymatic activity, as well as the uptake of ions by the roots of plants [1]. When the concentration of oxygen is below $1 \%$, the anaerobic conditions begin to prevail in the soil $[2,3]$. As a result of oxygen depletion, carbon metabolisms and nutrient

*e-mail:kfurtak@iung.pulawy.pl dynamics undergo changes. Under such conditions the enzymatic activity of the soil (mainly dehydrogenases), redox potential (Eh) and soil $\mathrm{pH}$ are affected [3]. In Europe, flood risk has increased in the last years [4], and the forecasts show that the climate change leads to an increase in the intensity of storms and flooding in Europe by 2100 [5].

In the soil environment there are many enzymes whose origin is related to microorganisms. Enzymes participate in the synthesis of proteins and nucleic acids, and they are also elements of the carbon, nitrogen and phosphorus cycle chains. Enzymatic activity depends on the type of microorganisms, their vitality, physical and chemical properties of soil and anthropogenic factors [6]. Dehydrogenases are part of the cellular respiratory pathway and catalyze oxidation and reduction reactions [7]. Phosphatase catalyzes the transformation of organic forms of phosphorus into inorganic phosphates available 
to plants [8]. Due to their function, the determination of the activity of these enzymes in soil is quite popular. In the opinion of scientists, enzymatic activity in combination with other soil properties provides sufficient information to evaluate soil quality [9].

The aim of this study was to analyze the changes occurring in the activity of selected enzymes during simulated flood conditions.

\section{Experimental}

\section{Soil and Water Samples}

Three different Fluvisols were taken from the Vistula floodplains of the Vistula River Gorge Lesser Poland in the Lubelskie Voivodeship. Selected locations are grassland located between a riverbed and a flood embankment. These areas are natural river floodplains, flooded from time to time. The mean annual temperature is $7.7^{\circ} \mathrm{C}$ in Wojszyn and $7.9^{\circ} \mathrm{C}$ in Janowiec. The mean annual precipitation is $537 \mathrm{~mm}$ in Wojszyn and $527 \mathrm{~mm}$ in Janowiec [10]. Fluvisols were selected on the basis of a soil and agricultural map (at $1: 25,000$ scale), which provided basic information of these soils. The selected soils are well known to be fertile, are in close proximity and are exposed to the same climatic conditions but differ in their granulometric composition (Table 1).

Locations of sampling, abbreviations of samples and basic physical-chemical parameters of selected soil are presented in Table 1. The exact characteristics and detailed comparison of the selected Fluvisols are presented in Furtak et al., 2019 [11].

Soil samples were collected in August 2018 as sods of $25 \mathrm{~cm}$ deep with living plants in three repetitions for each Fluvisol. In total, nine sods were placed in transparent polypropylene containers measuring $33 \times 33$ x $42 \mathrm{~cm}$. Each container had drains made at the bottom. Then it was placed in another container without drains.

At the same time, water was taken from the Vistula River in Janowiec, Lubelskie Voivodeship (51 ${ }^{\circ} 19^{\prime} 06.8^{\prime}$ 'N $21^{\circ} 54^{\prime} 53.5$ "E), above the place of soil sampling. The water was taken from the river at a distance of approx. 27 meters from the riverbank to sterile plastic containers. The $\mathrm{pH}$ of the water taken from the Vistula was 8.54 , and electrical conductivity was $370 \mu \mathrm{S} / \mathrm{cm}$.

\section{Simulating Flooding}

The containers with sampled Fluvisols were flooded with the collected river water at the level of $5 \mathrm{~cm}$ above the soil surface (about $12 \mathrm{~L}$ ). The samples were kept in a room with controlled conditions: temp. $24^{\circ} \mathrm{C}$, photoperiod $16 \mathrm{~h}$ of day and $8 \mathrm{~h}$ of night. The fixed water level was kept for 2 weeks and samples were collected weekly during stagnation of water (after 7 and 14 days) using a soil probe collector from the depth of the whole profile of $0-20 \mathrm{~cm}$. The soil was stored at $4^{\circ} \mathrm{C}$ before analysis.

\section{Methods Used for Soil Analysis}

\section{Soil pH}

The soil and water $\mathrm{pH}$ was measured potentiometrically. From each soil sample $10 \mathrm{~g}$ was suspended in $10 \mathrm{~mL}$ of sterile water and incubated at room temperature for $24 \mathrm{~h}$. After $24 \mathrm{~h} \mathrm{pH}$ was determined using a $\mathrm{pH}$ meter (edge multiparameter $\mathrm{pH}$ meter, HANNA Instrument, Woonsocket, RI, USA).

\section{Dehydrogenases Activity (DHA)}

The activity of soil dehydrogenases (DHA) was determined spectrophotometrically (UV-Vis Evolution 60 spectrophotometer, Thermo Fisher Scientific, Waltham, MA, USA). The assay was carried out according to the method of Casida et al. (1964) using TTC (2,3,5 - triphenyl-tetrazolium chloride) as a substrate [7]. DHA was expressed in micrograms of triphenyl formazan (TPF) per $1 \mathrm{~g}$ dry weight soil per 24 hours of incubation.

\section{Alkaline (AlP) and Acid (AcP) Phosphatase Activity}

The activity of alkaline (AlP) and acid (AcP) phosphatases was measured according to the method

Table 1. Characteristics of soil samples used in the experiment.

\begin{tabular}{|c|c|c|c|c|c|c|c|c|c|}
\hline \multirow{2}{*}{ Abbreviation } & \multirow{2}{*}{ Localization } & \multirow{2}{*}{ GPS coordinates } & \multicolumn{3}{|c|}{ Granulometric composition (mm) } & \multirow{2}{*}{$\mathrm{pH}_{\mathrm{H} 20}$} & \multirow{2}{*}{$\begin{array}{l}\mathrm{N}_{\text {tot. }} \\
(\%)\end{array}$} & \multirow{2}{*}{$\begin{array}{l}\mathrm{C}_{\text {tot. }} \\
(\%)\end{array}$} & \multirow{2}{*}{$\begin{array}{l}\mathrm{C}_{\text {org. }} . \\
(\%)\end{array}$} \\
\hline & & & $2.0-0.1$ & $0.1-0.02$ & $<0.02$ & & & & \\
\hline $\mathrm{F} 1$ & Wojszyn & $\begin{array}{l}51^{\circ} 20^{\prime} 03.4^{\prime \prime} \mathrm{N} \\
21^{\circ} 56^{\prime} 43.2^{\prime \prime} \mathrm{E}\end{array}$ & 47 & 26 & 27 & $7.50^{c}$ & $0.28^{\mathrm{a}}$ & $3.55^{\mathrm{a}}$ & $2.75^{\mathrm{a}}$ \\
\hline F2 & Janowiec & $\begin{array}{l}51^{\circ} 19^{\prime} 29.9^{\prime \prime} \mathrm{N} \\
21^{\circ} 55^{\prime} 19.2^{\prime \prime} \mathrm{E}\end{array}$ & 51 & 30 & 19 & $7.67^{\mathrm{a}}$ & $0.17^{\mathrm{b}}$ & $2.08^{\mathrm{b}}$ & $1.70^{\mathrm{b}}$ \\
\hline F3 & Janowiec & $\begin{array}{l}51^{\circ} 19^{\prime} 14.4^{\prime \prime} \mathrm{N} \\
21^{\circ} 54^{\prime} 42.9^{\prime \prime} \mathrm{E}\end{array}$ & 89 & 5 & 6 & $7.53^{\mathrm{b}}$ & $0.06^{\mathrm{c}}$ & $0.62^{\mathrm{c}}$ & $0.55^{\mathrm{c}}$ \\
\hline
\end{tabular}

$\mathrm{N}_{\text {tot. }}$ - total nitrogen content; $\mathrm{C}_{\text {tot. }}$ - total carbon content; $\mathrm{C}_{\text {org }}$ - organic carbon content; Different letters (a-c) in the columns indicate values with significant difference at $P \leq 0.01(n=3)$ by Tukey's HSD test. 
described by Tabatabai (1982) with $\rho$-nitrophenyl phosphate ( $\rho$-NPP) as a substrate [8]. The analysis was performed using a spectrophotometer described above. The activity of both phosphatases was reported as micrograms of $\rho$-nitrophenol (PNP) per $1 \mathrm{~g}$ dry weight soil per 1 hour of incubation.

\section{Statistical Analysis}

All laboratory analyses were performed in triplicates of each soil sample. Statistical analyses were performed using Statistica.PL ver. 10.0 (StatSoft. Inc., Tulsa, OK, USA). Significant differences were calculated according to ANOVA one-way post hoc Tukey's HSD (Tukey's honest significant difference) test with $P \leq 0.05$ significant level. The results were submitted to principal component analysis ( $\mathrm{PCa})$ in order to determine the common relations between parameters.

\section{Results and Discussion}

\section{Changes in Soil pH During Flooding}

The $\mathrm{pH}$ of the river water used to simulate the flood conditions was 8.54. During the experiment, as a result of water stagnation, the $\mathrm{pH}$ value of the examined soils decreased from alkaline to neutral (Table 2). After 14 days of simulated flood conditions the $\mathrm{pH}$ value decreased by $9.2 \%$ in $\mathrm{F} 3,10.9 \%$ in $\mathrm{F} 1$ and $11.6 \%$ in F2. The differences obtained in time were statistically significant at $P \leq 0.05$ both for individual soils in time and between different soils.

Water enables the diffusion of solvents and gases in the soil environment, the availability of nutrients, is an integral part of hydrolysis processes, and its amount determines the rate of mineralization [12]. This causes the water content in the soil to influence its $\mathrm{pH}$. When soil is initially saturated with water, the $\mathrm{pH}$ decreases due to the accumulation of carbonic acid formed from the retained carbon dioxide produced by respiration. Fermentation also contributes to lowering the $\mathrm{pH}$ by producing organic acids [13].

Studies have shown that under flooding conditions the $\mathrm{pH}$ of acidic soils increases, and the $\mathrm{pH}$ of alkaline soil decreases, approaching neutral conditions [14].
This is due to the accumulation of $\mathrm{CO}_{2}$ in the soil. Additionally, as a result of the decrease in oxygen concentration, the number of anaerobic microorganisms that carry out reduction and fermentation processes, which may also acidify the environment, increases [15]. In acidic soils an increase in $\mathrm{pH}$ [16] is observed, which results from a change in redox potential in soils.

No significant changes in $\mathrm{pH}$ values were also found in the case of soils sampled from horticultural areas in the middle Vistula River valley (Lublin Region) after the 2010 flood [17]. However, after the flood in 1997 in the area of the Oder River floodplain a significant decrease in $\mathrm{pH}$ of acidic soils (in Poland) was observed [18]. Also, a study on flooded rice soils conducted by Fageria et al. (2011) found that the $\mathrm{pH}$ of acidic soils increased and the $\mathrm{pH}$ of alkaline soils decreased [19]. This is consistent with our results, where the $\mathrm{pH}$ of tested soils (neutral to slightly alkaline) decreased significantly statistically after 14 days of water stasis. The opposite trend was observed in the case of flooding on the river floodplain in China (Xuzhou City, Jiangsu province), where the $\mathrm{pH}$ of soil (Leptosols) from slightly alkaline (7.48 and 7.61) increased (to 8.35 and 8.55) [14].

\section{Change in the Activity of Dehydrogenases in Soil During Water Stagnation}

As can be seen in Fig. 1, the activity of dehydrogenases significantly increased in all samples during the simulated flood experiment. In the F1 sample the activity of dehydrogenases increased more than three times between fresh soil and after 14 days of flooding. In the sample of F2 the increase was more than 4 times. The highest change was observed in soil F3, where after 14 days of water stagnation an 11 times higher activity of dehydrogenases was observed. It can also be noted that after 14 days of water stagnation there were large discrepancies in dehydrogenase activity in soils as boxes have a larger plot in the previous periods.

Dehydrogenases are responsible for the transport of electrons in the soil environment. They can use both $\mathrm{O}_{2}$ and other compounds as the final acceptor of electrons [20]. The activity of dehydrogenases is closely related to many processes occurring in the soil environment; it is affected by physical and chemical characteristics of soil, salinity and contamination with heavy metals

Table 2. Change in the $\mathrm{pH}$ value of soils during water stagnation.

\begin{tabular}{|c|c|c|c|}
\hline \multirow{2}{*}{ Soil sample } & \multicolumn{2}{|c|}{$\mathrm{pH}_{\mathrm{H} 2 \mathrm{O}}$} \\
\cline { 2 - 4 } & Fresh soil & After 7 days of simulated flooding & After 14 days of simulated flooding \\
\hline F1 & $7.50^{\mathrm{c}, \mathrm{x}}$ & $7.43^{\mathrm{a}, \mathrm{y}}$ & $6.68^{\mathrm{c}, \mathrm{z}}$ \\
\hline F2 & $7.67^{\mathrm{a}, \mathrm{x}}$ & $7.36^{\mathrm{b}, \mathrm{y}}$ & $6.78^{\mathrm{b}, \mathrm{z}}$ \\
\hline F3 & $7.53^{\mathrm{b}, \mathrm{x}}$ & $7.13^{\mathrm{c}, \mathrm{y}}$ & $6.84^{\mathrm{a}, \mathrm{z}}$ \\
\hline
\end{tabular}

Different letters (a-c) in the columns and (x-z) in the rows indicate values with significant difference at $P \leq 0.05(n=9)$ by Tukey's HSD test. 


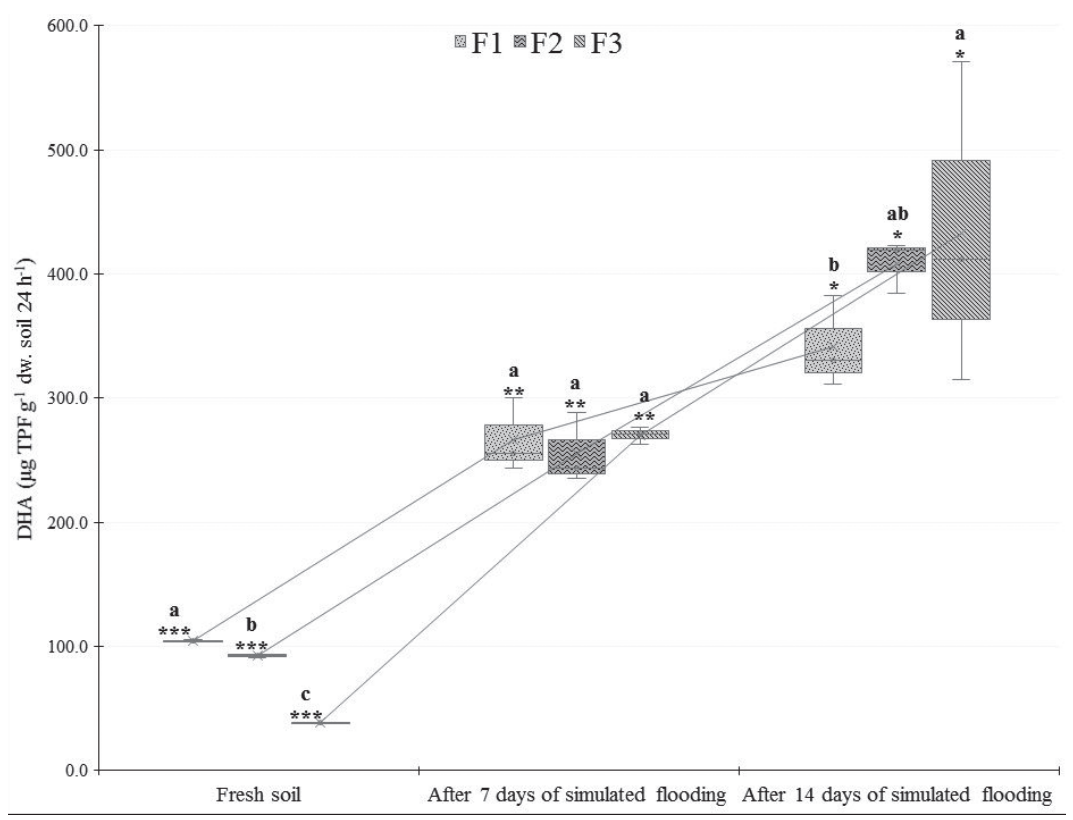

Fig. 1. Change in the activity of dehydrogenases in soil during simulated flooding.

Box plot: whiskers represents the minimum and maximum values, the horizontal line in the box indicates the median, " $\mathrm{X}$ " - average; values with different letters "a-c" indicate significant difference for different soils at the same time, and with different symbols "**, , ***, "***" indicate significant difference for the same soil in different times; both at $P \leq 0.05(n=27)$ by Tukey's HSD test.

and PAHs [21]. Dehydrogenases are one of the most sensitive indicators in soil analysis [22].

Much research has shown that soil moisture and its fluctuations have a big influence on dehydrogenase activity [15]. High DHA activity in soil was reported in the rainy season and the lowest in soil with low moisture [23]. Gu et al. (2009) observed a 90\% increase in DHa in flooded soil [24]. Similar results were obtained for trauma activity, which was also higher in flooded soil than in uninflated soil. In wetlands, dehydrogenase activity quickly increases to a high level [25]. Weaver et al. (2012) recorded a significant increase in DHA activity in rice fields during winter flooding [26]. High dehydrogenase activity may be caused by two factors. Firstly, as a result of flooding, dissolution and release of soluble organic compounds in soil may occur, which contributes to the development of a larger number of bacteria that secrete dehydrogenases [18, $25]$. The second cause may be the change of oxygen conditions to anaerobic conditions and the proliferation of anaerobic microorganisms. It has been shown that most of the dehydrogenases are produced by anaerobic microorganisms [20].

\section{Change of Phosphatase Activity in Soil During Simulated Floods}

The activity of phosphatases changed during the simulated flood conditions in different ways in the samples examined (Fig. 2a-b). In samples F1 and F2, both acidic and alkaline phosphatase activity decreased during water stagnation. While in sample F3 the activity of both phosphatases decreased after 7 days of water stagnation, but increased slightly after another 7 days of flooding. However, this changes was not statistically significant at $\mathrm{P} \leq 0.05$. Changes in phosphatases activity were statistically significant at $\mathrm{P} \leq 0.05$ in sample $\mathrm{F} 1$ (both phosphatases) and sample F2 in the case of alkaline phosphatase activity (Fig. 2b).

Phosphatases are enzymes catalyzing the hydrolysis of esters and anhydrides of orthophosphoric acid [27]. In soil, they are responsible for the transformation of organic forms of phosphorus into inorganic phosphates, which are directly available to plants. This is an important process from the point of view of agriculture, as it is estimated that about $40 \%$ of soils in Poland are poor with phosphorus available [28].

The phosphatase activity in soil can be used as an indicator of the mineralization potential of organic phosphorus, and thus of the biological activity of the soil. It was shown that phosphatases activity is related to soil properties, mainly to soil $\mathrm{pH}$, moisture and microbial abundance [29]. The observed significant decrease in alkaline phosphatase activity in samples F1 and F2 during the experiment is related to the change in soil $\mathrm{pH}$. Alkaline phosphatase has an optimum $\mathrm{pH}$ between 8-10 [30], and acidification of the environment causes its decrease [31]. Acid phosphatase, however, shows an optimum in the range of 4-6 [30], and probably because of that no significant differences in AcP activity were observed in F2 and F3 samples.

Microorganisms synthesizing phosphatase include representatives of Bacillus, Pseudomonas, Arthrobacter, and Aerobacter, among which most of the species are aerobic microorganisms, which in the absence of oxygen, whose concentration decreases as a result of 

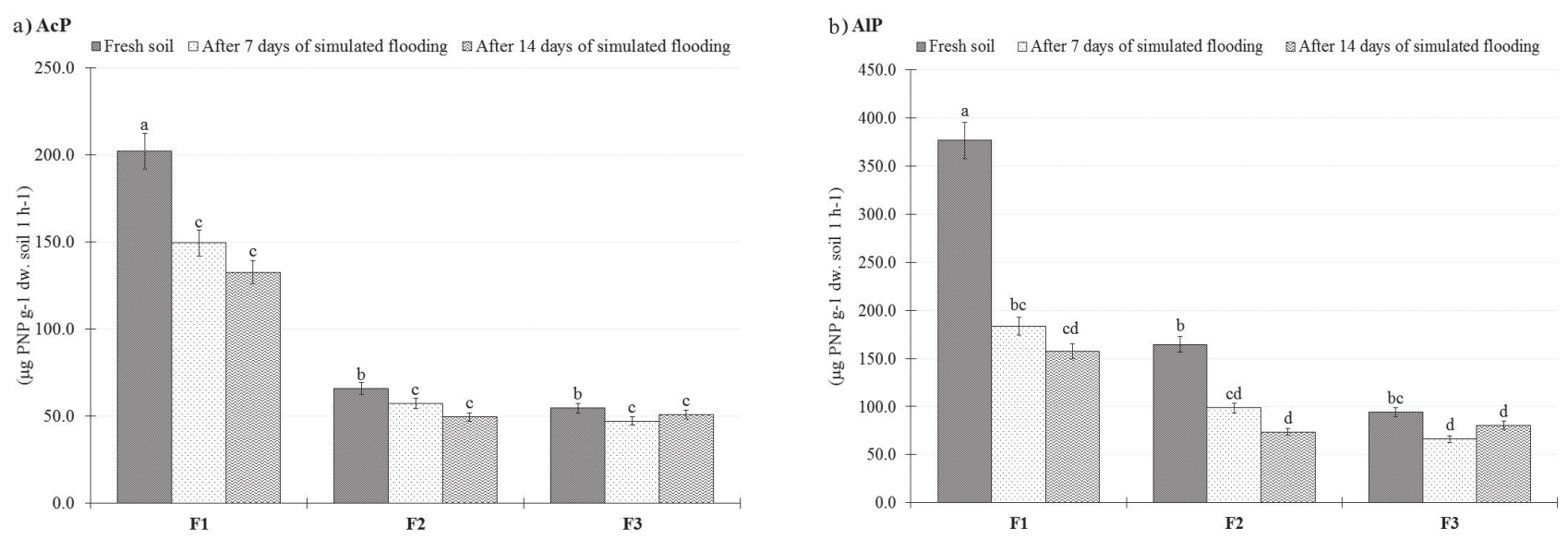

Fig 2. Change in the activity of phosphatases in soil during simulated flooding: a) AcP - acid phosphatase activity; b) AlP - alkaline phosphatase activity.

Values with different letters "a-c" indicate significant difference at $P \leq 0.05(\mathrm{n}=27)$ by Tukey's HSD test; vertical bars represented SD.

increased humidity, die. Phosphatases are also sensitive to too low soil moisture. It was shown that the decrease of water availability in soil by $21 \%$ results in the decrease of acid phosphatase activity by $31-40 \%$ [32]. We observed a statistically significant decrease in the activity of alkaline phosphatase in F1 and F2, and AcP in the F1 sample after 7 days of simulated flooding. Also, the research of Borowik and Wyszkowska (2016) noted that with an increase in soil moisture, phosphatase activity decreased significantly statistically, and the highest phosphatase activity was recorded in soil with $20 \%$ moisture [33].

We analyzed three Fluvisols with different textures in which the phosphatase activity under the influence of flooding changed differently. Differences of enzymatic reaction in examined soils may result from different

Table 3. Pearson's correlation coefficient of soil $\mathrm{pH}$ and enzymatic activity during simulated flood conditions: A) for fresh soils, B) for soils after 7 days of simulated flooding, and C) for soils after 14 days of simulated flooding.

\begin{tabular}{|c|c|c|c|c|}
\hline \multicolumn{5}{|c|}{ A) Fresh soils } \\
\hline & DHa & AcP & AlP & $\mathrm{pH}$ \\
\hline DHa & 1 & $0.6923^{*}$ & $0.8061^{*}$ & $0.9939^{*}$ \\
\hline $\mathrm{AcP}$ & $0.6923^{*}$ & 1 & $0.9846^{*}$ & 0.6162 \\
\hline AlP & $0.8061^{*}$ & $0.9846^{*}$ & 1 & $0.7421^{*}$ \\
\hline $\mathrm{pH}$ & $0.9939^{*}$ & 0.6162 & $0.7421^{*}$ & 1 \\
\hline \multicolumn{5}{|c|}{ B) Soils after 7 days of simulated flooding } \\
\hline & DHa & AcP & AlP & $\mathrm{pH}$ \\
\hline $\mathrm{DHa}$ & 1 & 0.0287 & -0.1750 & -0.1065 \\
\hline AcP & 0.0287 & 1 & $0.9558^{*}$ & $0.7923 *$ \\
\hline AlP & -0.1750 & $0.9558^{*}$ & 1 & $0.8378^{*}$ \\
\hline $\mathrm{pH}$ & -0.1065 & $0.7923 *$ & $0.8378^{*}$ & 1 \\
\hline \multicolumn{5}{|c|}{ C) Soils after 14 days of simulated flooding } \\
\hline & DHa & AcP & AlP & $\mathrm{pH}$ \\
\hline DHa & 1 & -0.2910 & -0.1554 & -0.5307 \\
\hline $\mathrm{AcP}$ & -0.2910 & 1 & $0.9027^{*}$ & $0.8250 *$ \\
\hline $\mathrm{AlP}$ & -0.1554 & $0.9027^{*}$ & 1 & 0.6614 \\
\hline $\mathrm{pH}$ & -0.5307 & $0.8250^{*}$ & 0.6614 & 1 \\
\hline
\end{tabular}

DHa - dehydrogenases activity; AcP - acid phosphatase activity; AlP - alkaline phosphatase activity; the values with “*” are statistically significant at $P \leq 0.05(n=9)$. 


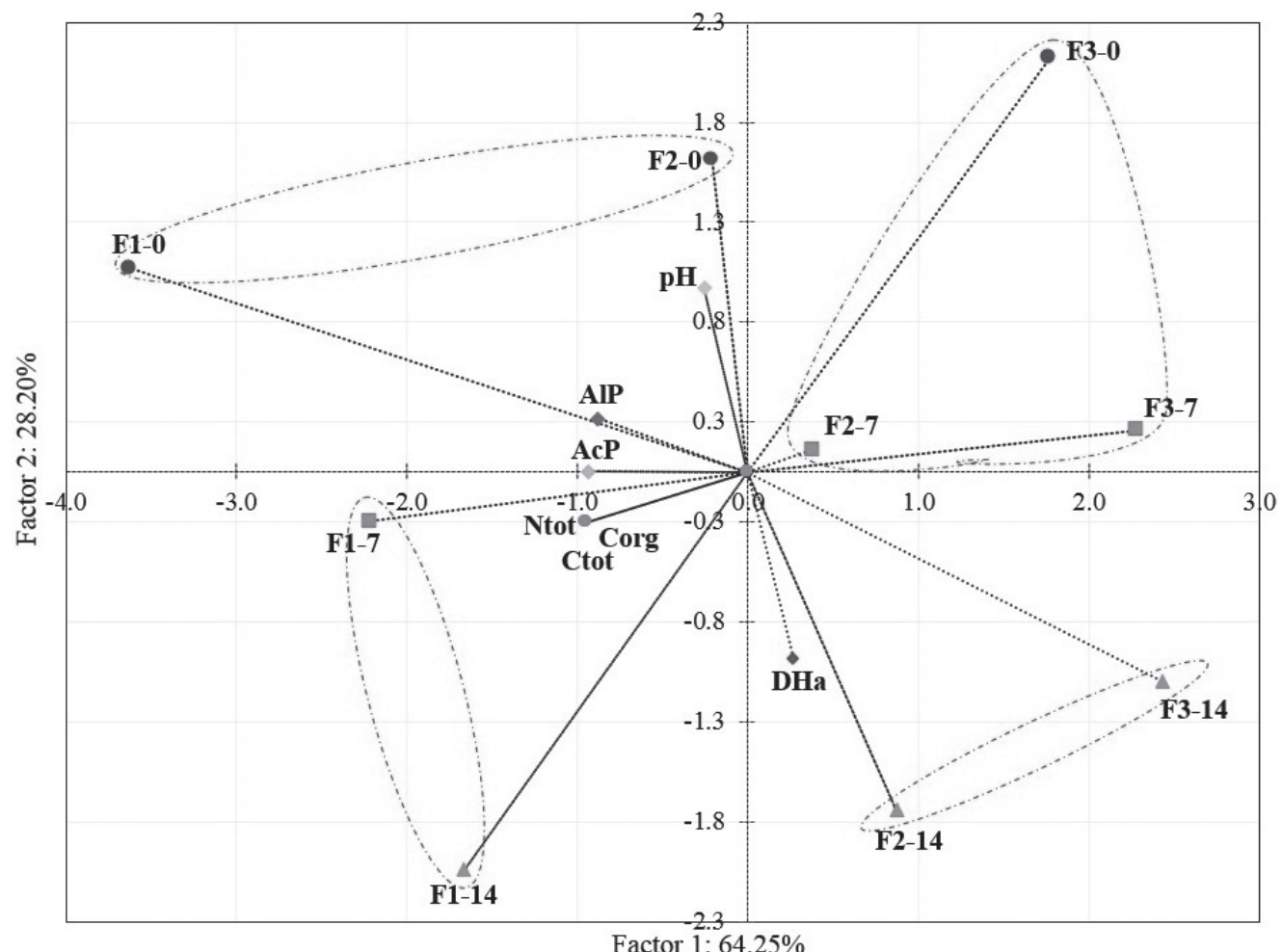

Fig. 3. Principal component analysis (PCA) enzymatic activity and physical-chemical parameters of soil.

DHA - dehydrogenases activity; AcP - acid phosphatase activity; AlP - alkaline phosphatase activity; Ntot - nitrogen total content; Ctot - carbon total content; Corg - carbon organic content; F1/2/3-0 - fresh soils; F1/2/3-7 - soils after 7 days simulated flooding; F1/2/3-14 - soils after 14 days simulated flooding.

granulometric composition. It is known that the soil texture affects the abundance of microorganisms in the soil and their activity [34].

\section{Correlations}

Correlations between $\mathrm{pH}$ values and enzymatic activity of the examined soils changed during the experiment (Table 3A-C). Statistically significant positive correlations (at $P \leq 0.05$ ) among the values obtained from all samples were obtained between the activity of acid phosphatase (AcP) and alkaline phosphatase (AlP). In fresh soils positive correlations between DHa, AcP, AlP and $\mathrm{pH}$ were obtained (Table 3A). During the simulated flood conditions the correlations of other parameters with DHa were changed to negative and statistically insignificant (Table 3C).

Although Huang et al. (2011) obtained a negative correlation between AcP activity and soil $\mathrm{pH}$, the soil $\mathrm{pH}$ analyzed by them during the rainy season increased (in comparison to the dry season) [35]. In the studied Fluvisols, increased humidity caused soil acidification that resulted in a statistically significant positive correlation between AcP and $\mathrm{pH}$ even after 14 days of flooding.

Literature data indicate that DHa correlates with both soil $\mathrm{pH}$ and moisture [23]. In this research, a statistically significant positive correlation between DHa and $\mathrm{pH}$ (0.994) was obtained only in fresh soil samples
(Table 3). However, after flooding, this correlation changes to a negative, statistically insignificant one (-0.106 after 7 days, and -0.531 after 14 days).

Based on the biplot (Fig 3.) it can be observed that the analyzed soils (from different sampling dates) formed 4 groups: 1) F1 and F2 fresh; 2) F3 fresh, F2 and F3 after 7 days of simulated flooding; 3) F1 after 7 and 14 days of simulated flooding; 4) F2 and F3 after 14 days of simulated flooding. In addition, it can be observed that the activity of both phosphatases and $\mathrm{pH}$ were positively correlated with each other, while the activity of dehydrogenases (DHa) correlates negatively with them. These results are in accordance with the data shown Table 3.

The activity of dehydrogenases is positively correlated with two soils (F3 and F2) after 14 days of flooding. Fresh samples of F1 and F2 are not correlated with soils obtained after 7 days of flooding. Soil F2 is additionally negatively correlated with soil collected after 14 days of water stagnation.

\section{Conclusions}

The results obtained in the simulated flood experiment indicate that water stagnation on soils causes significant changes in soil enzymatic activity. A statistically significant decrease in soil $\mathrm{pH}$ confirms that during the flood the soil environment was 
significantly acidified. The increase in dehydrogenase activity in flooded soil indicates the importance of anaerobic microorganisms in the formation of dehydrogenases, which is in accordance with literature data.

The soil high moisture content is a significant factor that changes the enzymatic activity of soil. Such changes in the soil environment may affect the quality of soil and thus the yield of plants. Therefore, the monitoring of changes occurring in soil as a result of flooding is important from the point of view of agriculture.

\section{Acknowledgements}

The research was conducted within the grant for young scientists in IUNG-PIB (MNiSW): "Influence of summer floods on changes in structural and functional biodiversity of microbiomes of selected river muds" (2018) and by Task 1.4. "Evaluation and formation of biodiversity of soil and microbial activity of soil with regard to habitat conditions and management system," Multi-Annual Programme IUNG - PIB (2016-2020).

\section{Conflict of Interest}

The authors declare no conflict of interest.

\section{References}

1. BALAKHNINA T., BENNICELLI R., STĘPNIEWSKA Z., STĘPNIEWSKI W., BORKOWSKA A., FOMINA I. Stress responses of spring rape plants to soil flooding. International Agrophysics, 26, 347, 2012.

2. GIANFREDA L., RAO M.A., PIOTROWSKA A., PALUMBO G., COLOMBO C. Soil enzyme activities as affected by anthropogenic alterations: intensive agricultural practices and organic pollution. Science of the Total Environment, 341, 265, 2005.

3. MHUANTONG W., WONGWILAIWALIN S., LOATHANACHAREON T., EURWILAICHITR L., TANGPHATSORNRUANG S., BOONCHAYAANT B., LIMPIYAKORN T., PATTARAGULWANIT K., PUNMATHARITH T., MCEVOY J., KHAN E., RACHAKORNKIJ M., CHAMPREDA V. Survey of Microbial Diversity in Flood Areas Turing Thailand 2011 Flood Crisis Using High-Throughput Tagget Amplicon Pyrosequencing. PLoSOne, 10, 5, e0128043, 2015.

4. BLÖSCHL G., HALL J., PARAJKA J., PERDIGÃO R.A.P., MERZ B., ARHEIMER B., ARONICA G.T., BILIBASHI A., BONACCI O., BORGA M., ČANJEVAC I., CASTELlARIN A., CHIRICO G.B., CLAPS P., FIALA K., FROLOVA N., GORBACHOVA L., GÜL A., HANNAFORD J., HARRIGAN S., KIREEVA M., KISS A., KJELDSEN T.R., KOHNOVÁ S., KOSKELA J.J., LEDVINKA O., MACDONALD N., MAVROVAGUIRGUINOVA M., MEDIERO L., MERZ R., MOLNAR P., MONTANARI A., MURPHY C., OSUCH M., OVCHARUK V., RADEVSKI I., ROGGER M., SALINAS
J.L., SAUQUET E., ŠRAJ M., SZOLGAY J., VIGLIONE A., VOLPI E., WILSON D., ZAIMI K., ŽIVKOVIĆ N. Changing climate shifts timing of European floods. Science, 357, 588, 2017.

5. VOUSDOUKAS M. I., MENTASCHI L., VOUKOUVALAS E., VERLAAN M., FEYEN L. Extreme sea levels on the rise along Europe's coasts. Earth's Future, 5, 304, 2017.

6. UTOBO E.B., TEWARI L. Soil enzymes as bioindicators of soil ecosystem status. Appl Ecol Env Res., 13 (1), 147, 2014.

7. CASIDA L., KLEIN D., SANTORO T. Soil dehydrogenase activity. Soil Science, 98, 371, 1964.

8. TABATABAI M.A. Soil enzymes. In Methods of Soil Analysis, $2^{\text {nd }}$ ed.; Page A.L., Miller R.H., Keeney D.R., Eds., American Society of Agronomy Inc. and Soil Science Society of America Inc.: Madison, Wisconsin, USA, Part 2, Number 9, 903, 1982.

9. FURTAK K., GAJDA A.M. Activity of dehydrogenases as an indicator of soil environment quality. Pol. J. Soil Sci., 50, 1, 33, 2017.

10. Climate-data.org. Available online: https://pl.climate-data. org (accessed on 11 January 2019).

11. FURTAK K., GRZĄDZIEL J., GAŁĄZKA A., NIEDŹWIECKI J. Analysis of Soil Properties, Bacterial Community Composition, and Metabolic Diversity in Fluvisols of a Floodplain Area. Sustainability, 11, 3929, 2019.

12. YAN N., MARSCHNER P., CAO W., ZUO C., QIN W. Influence of salinity and water content on soil microorganisms. International Soil and Water Conservation Research, 3, 316, 2015.

13. Central Metabolism (Flooded soils). Avaliable online: https://microbewiki.kenyon.edu/index.php/Central Metabolism (Flooded soils) (accessed 13.06.2019).

14. TIAN J., DONG G., KARTHIKEYAN R., LI L., HARMEL R.D. Phosphorus dynamics in long-term flooded, drained, and reflooded soils. Water, 9, 531, 1, 2017.

15. WOLIŃSKA A. Dehydrogenase activity of soil microorganisms and oxygen availability during reoxidation process of selected mineral soils from Poland. Acta Agrophysica, Rozprawy i Monografie, 3, 180, 12, 2010 [In Polish].

16. WŁODARCZYK T., SZARLIP P., BRZEZIŃSKA M., KOTOWSKA U. Redox potential, nitrate content and $\mathrm{pH}$ in flooded Eutric Cambisol during nitrate reduction. Res. Agr. Eng., 53 (1), $20,2007$.

17. BEDNAREK W., DRESLER S., TKACZYK P., HANAKA A. 2014. Physicochemical properties of surface soil layer after the flood in the middle Vistula River valley. J. Elem. 1, 17, 2014.

18. KUCHARZEWSKI A., NOWAK L. Effect of the 1997 flood on the content of microelements in surface soil layer of Wroclaw province. Zesz. Probl. Post. Nauk Rol., 471, $367,2000$.

19. FAGERIA N.K., CARVALHO G.D., SANTOS A.B., FERREIRA E.P.B., KNUPP A.M. 2011. Chemistry of lowland rice soils and nutrient availability. Comm. Soil Sci. Plant Anal., 42 (16), 1913, 2011.

20. WOLIŃSKA A., STĘPNIEWSKA Z. Dehydrogenase activity in the soil environment. In Dehydrogenases; Canuta R.A., Eds., IntechOpen, Lodnon, UK, 183, 2012.

21. TELESIŃSKI A., DOBROWOLSKA A., STRĘK M., PŁATKOWSKI M., ONYSZKO M. Comparison of some heavy metal and salinity effects on enzymatic activity in horticultural growing media used in pot 
technology of lavender (Lavandula angustifolia Mill.) production. Woda-Środowisko-Obszary Wiejskie, 15, 1, 123, 2015 [In Polish].

22. SALAZAR S., SANCHEZ L., ALVAREZ J., VALVERDE A., GALINDO P., IGUAL J., PEIX A., SANTA-REGINA I. Correlation among soil enzyme activities under different forest system management practices. Ecological Engineering, 37, 1123, 2011.

23. KUMAR S., CHAUDHURI S., MAITI S.K. Soil dehydrogenase enzyme activity in natural and mine soil - a review. Middle-East Journal of Scientific Research 13 (7), 898, 2013.

24. GU Y., WAG P., KONG C. Urease, Invertase, Dehydrogenase and Polyphenoloxidase Activities In Paddy Soils Influenced By Allelopathic Rice variety. European Journal of Soil Biology, 45, 436, 2009.

25. SUBHANI A., CHANGYONG H., ZHENGMIAO Y., MIN L., EL-GHAMRY A. Impact of Soil Environment and Agronomic Practices On Microbial/Dehydrogenase Enzyme Activity In Soil. A Review. Pakistan Journal of Biological Sciences, 4, 333, 2001.

26. WEAVER M., ZABLOTOWICZ R., KRUTZ L., BRYSON C., LOCKE M. Microbial and Vegetative Changes Associated With Development of a Constructed Wetland. Ecological Indicators, 13, 37, 2012.

27. BHAGAWATI T., SAMANTA R. Phosphatases of soils and microbes of tea gardens of Dibrugarh District, Assam. Indian J Appl Res, 5 (5), 19, 2015.

28. KOZIEŁ M., GA $€$ ĄZKA A. Number of microorganisms dissolving phosphates from mineral compounds in agricultural soil from Poland. Studia i Raporty IUNG-PIB, 2017, 54 (8), 83, 2017 [In Polish].

29. GAŁĄZKA A., GAWRYJOŁEK K., KOCOŃ A. Number of microorganisms dissolving phosphates and phosphatase activity in soil in the context of the use of microbiological preparations. Studia i Raporty IUNG-PIB, 54 (8), 95, 2017 [In Polish].

30. BANERJEE A., SANYAL S., SEN S. Soil phosphatase activity of agricultural land: A possible index of soil fertility. Agricultural Science Research Journals, 2 (7), 412, 2012.

31. BIELIŃSKA E.J. Methods of determination of photosphatase activity. Rozprawy i Monografie, 3, 63, 2005 [In Polish.

32. SARDANS J., PEÑUELAS J. Drought decreases soil enzyme activity in a Mediterranean Quercus ilex L. forest. Soil Biology and Biochemistry, 37, 3, 455, 2005.

33. BOROWIK A., WYSZKOWSKA J. Soil moisture as a factor affecting the microbiological and biochemical activity of soil. Plant Soil Environ. 62, 6, 250, 2016.

34. MELIANI A., BENSOLTANE A., MEDERBEL K. Microbial diversity and abundance in soil: related to plant and soil type. American Journal of Plant Nutrition and Fertilization Technology, 2 (1), 10, 2012.

35. HUANG W., LIU J., ZHOU G., ZHANG D., CEND Q. Effects of precipitation on soil acid phosphatase activity in three successional forests in southern China. Biogeosciences, 8, 1901, 2011. 